\title{
HUBUNGAN ANTARA STRESS KERJA DENGAN PRODUKTIVITAS KERJA PADA PEKERJA BAGIAN PRODUKSI
}

\author{
Herlinawati*, Laelatul Qodriyah**
}

\begin{abstract}
ABSTRAK
Berdasarkan data dari produktivitas pegawai PT.Cipta Rasa Utama Kabupaten Cirebon pada bulan Maret hingga Mei tahun 2014 terjadi penurunan produktivitas pada pegawai bagian produksi packing yang dimungkinkan dipengaruhi oleh indikator stres kerja (sering mengalami pusing, sakit kepala, gangguan pencernaan, tidak bisa mengontrol emosi, mudah marah, dan tidak bisa berkonsentrasi selama bekerja). Penelitian ini bertujuan untuk mengetahui Hubungan antara Stres Kerja dengan Produktivitas Kerja Pada Pekerja Bagian Produksi di PT.Cipta Rasa Utama Kabupaten Cirebon tahun 2014. Jenis penelitian ini adalah observasional analitik dengan pendekatan Cross sectional populasi penelitian ini adalah pegawai bagian produksi packing sebanyak 45 responden pegawai bagian produksi yang bekerja di PT.Cipta Rasa Utama Cirebon. Sampel diambil dengan metode Simple Random sampling dengan undian Teknik pengumpulan data dengan menggunakan wawancara dan studi dokumentasi data hasil produksi dari PT.Cipta Rasa Utama. Teknik pengolahan dan analisis data dilakukan dengan uji statistik Rank spearman pada tingkat kemaknaan 5\% atau (0,05).Hasil uji statistik analisis menggunakan rumus Rank Spearman diperoleh nilai $\rho=0,03$ pada taraf kepercayaan $5 \%$ karena nilai $\rho=0,03$ lebih kecil dari $0,05(0,03 \leq 0,05)$ sehingga Ha diterima yang menyatakan ada hubungan antara stres kerja dengan tingkat produktivitas kerja pada bagian produksi PT.Cipta Rasa Utama Kabupaten Cirebon Tahun 2014.
\end{abstract}

Kata Kunci : Stres Kerja, Produktivitas Kerja

\section{ABSTRACK}

Based on the results of employee productivity data PT.Cipta Major Pain Cirebon in March to May 2014 there is a decrease in employee productivity made possible the production of packing is affected by occupational stress indicator (often experience dizziness, headache, indigestion, can not control emotions, irritable, and unable to concentrate during work). This study aims to determine the relationship between Work Stress At Work Productivity Part Production Workers in Major Pain PT.Cipta Rasa Utama Cirebon in 2014. The study design was observational with cross sectional approach. The samples were 45 respondents employees who work in the production of the Main Pain PT.Cipta Cirebon. Samples taken with the way the draw random sampling method. Data collection techniques using the checklist sheet and if the production data of the Main Pain PT.Cipta. Processing techniques and data analysis was done by Spearman Rank statistik test at a significance level of 5\% or (0.05). Statistical analysis of test results using the Spearman Rank formula obtained value of $\rho=0.03$ at $5 \%$ confidence level because the value of $\rho=0.03$ is smaller than $0.05(0.03 \leq$ 0.05) Ha received stating that there is a relationship between work stress to the productivity of labor in the production PT.Cipta Rasa Utama Cirebon 2014.

Keywords: Job stress, work productivity

\footnotetext{
* Staf Pengajar Program Studi S1 Kesehatan Masyarakat STIKes Cirebon

** Alumni PSKM STIKes Cirebon Lulus Tahun 2014
} 


\section{PENDAHULUAN}

Setiap orang dalam suatu organisasi, dapat berperan sebagai sumber stres bagi oranglain. Mengelola stres bagi diri sendiri berarti mengendalikan diri sendiri dalam kehidupan. Sebagai seorang manajer, mengelola stres pekerja ditempat kerja lebih bersifat pemahaman akan penyebab stres oranglain dan mengambil tindakan untuk menguranginya dalam rangka pencapaian tujuan perusahaan. Efektivitas proses komunikasi dua arah diantara manajer dan pekerja adalah penting untuk mengidentifikasikan penyebab stres dan pemecahannya, karena stres akan selalu terjadi pada pekerja. ${ }^{1}$ Stres kerja biasanya diasosiasikan dengan situasi di mana karyawan dihadapkan pada bermacam-macam tuntutan sedang dia hanya mempunyai sedikit otoritas dan kontrol. ${ }^{1}$

Akan tetapi pada dasarnya stres tidak selalu berarti negatif. Tetapi apabila stres yang dirasakan oleh karyawan dalam pekerjaannya yang sangat besar dan melebihi kapasitas seseorang untuk menyelesaikannya maka terjadilah stres terhadap pekerjaan. Sehingga apabila karyawan merasakan adanya tekanan dalam kerja, ada kemungkinan karyawan tersebut mengalami stres kerja yang dapat menjadikan bekerja lebih lamban, meningkatnya konsumsi rokok dan minuman beralkohol. Hal seperti ini lama-kelamaan dapat berkembang menjadi kebiasaan yang merupakan faktor beresiko terhadap penyakit tertentu. Kesehatan baik fisik maupun psikis dapat berpengaruh terhadap semangat kerja seseorang. Adanya gangguan penyebab individu menjadi tidak bergairah, tidak mempunyai semangat untuk bekerja, sehingga akan mempengaruhi produktivitas kerja. ${ }^{2}$

Karyawan memegang peran utama dalam menjalankan roda kehidupan perusahaan. Karyawan dinilai produktif apabila mampu menghasilkan output atau produk yang lebih besar dari tenaga kerja lain untuk satuan waktu yang sama. Dan seorang karyawan menunjukan tingkat produktivitas yang tinggi apabila mampu mengasilkan produk yang sesuai dengan standar yang ditentukan, dalam satuan waktu yang lebih singkat. ${ }^{3}$

Di berbagai perusahaan sering terjadi penurunan produktivitas karyawan yang dikarenakan kemungkinan adanya ketidaknyamanan dalam bekerja, upah yang rendah. Kadangkala produktivitas kerja seorang karyawan cenderung menurun dan pengaruhnya adalah merosotnya suatu perusahaan. Produktivitas sekitar $90 \%$ bergantung kepada kinerja tenaga kerja, dan yang $10 \%$ bergantung kepada perkembangan teknologi dan bahan mentah. ${ }^{4}$ Dalam hal ini dimungkinkan adanya permasalahan yang terjadi pada lingkungan perusahaan khususnya di PT.Cipta Rasa Utama-Cirebon dimana stres kerja dapat dimungkinkan berpengaruh terhadap produktivitas kerja. Perusahaan PT.Cipta Rasa Utama merupakan salah satu perusahaan yang memproduksi makanan ringan yang juga mungkin tidak luput dari permasalahan dengan produktivitas kerja. ${ }^{4}$

Berdasarkan data dari PT.Cipta Rasa Utama yang di dapat pada tanggal02 Juni 2014, menunjukkan bahwa hasil produksi makanan ringan per bulan terhitung dari tanggal 01 Maret 2014 hingga 31 Maret 2014 bagian packing atau pembungkusan sudah menghasilkan 53.000 dus makanan ringan dengan hasil produksi yang utuh atau sempurna sebesar 52.600 dusdan hasil produksi yang cacat sebanyak 400 dus. Hasil produksi pada tanggal 01 April 2014 hingga 30 April 2014 bagian packing atau pembungkusan, menghasilkan 53.000 dus makanan ringan dengan hasil produksi yang utuh atau sempurna 52.500 dus dan hasil produksi yang cacat sebanyak 500 dus. Didapat pula data hasil produksi PT.Cipta Rasa Utama pada tanggal 01 Mei 2014 hingga 31 Mei 2014 bagianpacking atau pembungkusan menghasilkan 53.000 dus makanan ringan dengan hasil produksi yang utuh atau sempurna 52.450 dus dan hasil produksi yang cacat sebanyak 550 dus. Hal tersebut menunjukan adanya penurunan produktivitas karyawan. ${ }^{4}$

Meningkatnya produksi yang dihasilkan tidak hanya tergantung pada mesin-mesin yang modern, modal yang cukup, dan bahan baku yang banyak, tetapi tergantung kepada orang yang melaksanakan pekerjaan. Tenaga kerja sebagai pelaksana dalam kegiatan perusahaan harus diarahkan untuk mencapai tingkat produktivitas yang optimal, dimana juga harus didukung dengan lingkungan kerja yang nyaman, jumlah jam kerja yang tidak terlalu padat, serta beban kerja yang tidak terlalu besar untuk mencapai hasil yang ditargetkan. ${ }^{5}$

Hasil studi pendahuluan dengan wawancara terhadap 45 karyawan bagian produksi PT.Cipta Rasa Utama adanya keluhan para karyawan bagian produksi PT.Cipta Rasa Utama yaitu sering 
mengalami pusing atau sakit kepala,gangguan pencernaan dan tidak bisa mengontrol emosi atau mudah marah. Hal ini merupakan indikasi adanya stres kerja pada karaywan. ${ }^{5}$

Stres yang dialami karyawan akan sangat berpengaruh terhadap hasil produksi, hasil produksi yang meningkat setiap bulannya itu menandakan sedikitnya gejala stres atau bahkan tidak terindikasi gejala stres pada karyawan bagian produksi. Akan tetapi jika produksi menurun atau hasil produksi bulan terakhir lebih sedikit dibandingkan dengan bulan sebelumnya, hal tersebut menandakan adanya gejala stres pada karyawan bagian produksi. Tujuan dalam penelitian ini adalah untuk mengetahui hubungan antara stres kerja dengan produktivitas kerja pada pekerja bagian produksi di PT.Cipta Rasa Utama Kabupaten Cirebon tahun 2014.

\section{METODE PENELITIAN}

Pada penelitian ini, peneliti menggunakan penelitian penjelasan (Explanatory Research). Metode yang digunakan adalah metode survey dengan pendekatan cross-sectional. ${ }^{6}$ Populasi adalah pekerja bagian produksi bagian packing atau pembungkusan di PT.Cipta Rasa Utama Cirebon pada periode bulan Januari sampai Agustus tahun 2014 yang berjumlah 85 orang. ${ }^{7}$ Sampel penelitian ini adalah sebagian yang diperoleh dari keseluruhan obyek yang diteliti dan dianggap mewakili seluruh populasi. $^{7}$

Besar sampel dalam penelitian ini :

$$
\mathrm{n}=\frac{\mathrm{Z}^{2}{ }_{1-\mathrm{a} / 2} \mathrm{P}(1-\mathrm{P}) \mathrm{N}}{\mathrm{d}^{2}(\mathrm{~N}-1)+\mathrm{Z}^{2}{ }_{1-\mathrm{a} / 2} \mathrm{P}(1-\mathrm{P})}
$$

Jumlah sampel sebesar 45 bekerja di bagian packing di PT Cipta Rasa Utama. Metode pengambilan sampel dengan simple random sampling dengan cara undian. Instrumen dalam penelitian ini adalah kuesioner. Metode pengumpulan data untuk kuesioner stress menggunakan angket dan untuk variabel produktivitas kerja menggunakan studi dokumentasi. Analisis data terdiri dari analisis univariat untuk menggambarkan distribusi dan persentase dari tiap variabel dan analisis bivariat mencari hubungan variabel bebas atau stress kerja dan variabel terikat atau produktivitas kerja dengan uji statistik Rank Spearman (taraf kepercayaan $a=5 \%$ ).

\section{HASIL PENELITIAN}

\section{Stres kerja}

Tabel 1 Distribusi Frekuensi Indikator Stres Kerja Pegawai Bagian Produksi

\begin{tabular}{clcc}
\hline No & \multicolumn{1}{c}{ Tingkat Stres } & Frekuensi & Persen $(\%)$ \\
\hline 1 & Sangat Tidak Pernah & 8 & 17,8 \\
2 & Tidak pernah & 1 & 2,2 \\
3 & Kadang-kadang & 27 & 60,0 \\
4 & Sering & 1 & 2,2 \\
5 & Sangat Sering & 8 & 17,8 \\
\hline \multicolumn{2}{r}{ Jumlah } & 45 & 100,0 \\
\hline
\end{tabular}

Tabel 1 menunjukan bahwa persentase pekerja dalam kategori stress sangat sering sebesar 17,8\% dan paling banyak mengalami stress pada kategori kadang-kadang sebesar $60 \%$. 


\section{Produktivitas Kerja}

Tabel 2 Distribusi Frekuensi hasil Produktiuvitas

\begin{tabular}{clcc}
\hline No & Tingkat Produktivitas Kerja & Frekuensi & Persen (\%) \\
\hline 1 & Tinggi & 19 & 42,2 \\
2 & Rendah & 26 & 57,8 \\
& & 45 & 100 \\
\hline
\end{tabular}

Tabel 2 menunjukan bahwa 57,8\% karyawan mempunyai produktivitasnya rendah.

\section{Hubungan Antara Stres Kerja dengan Produktivitas Kerja}

Tabel 3 Hubungan Antara Stres Kerja Dengan Produktivitas Kerja

\begin{tabular}{|c|c|c|c|c|c|c|c|c|}
\hline \multirow{2}{*}{ No } & \multirow{2}{*}{ Stres Kerja } & \multicolumn{4}{|c|}{ Produktivitas Kerja } & \multicolumn{2}{|c|}{ Total } & \multirow{2}{*}{ P Value } \\
\hline & & Rendah & $\%$ & Tinggi & $\%$ & $\mathrm{~N}$ & $\%$ & \\
\hline 1 & Sangat Tidak Pernah & - & - & 8 & 100,0 & 8 & 100,0 & \multirow{6}{*}{0,03} \\
\hline 2 & Tidak pernah & - & - & 1 & 100,0 & 1 & 100,0 & \\
\hline 3 & Kadang-kadang & - & - & 1 & 100,0 & 27 & 100,0 & \\
\hline 4 & Sering & 20 & 74,1 & 7 & 25,9 & 27 & 100,0 & \\
\hline 5 & Sangat Sering & 6 & 75,0 & 2 & 25,0 & 8 & 100,0 & \\
\hline & Jumlah & 26 & 99,1 & 19 & 400,9 & 45 & 100,0 & \\
\hline
\end{tabular}

Tabel diatas menunjukkan bahwa responden yang sering stress sebagian besar memiliki produktivitas rendah $(74,1 \%)$ begitu juga responden yang sangat sering stres sebagian besar (75\%) memiliki produktivitas yang rendah sedangkan responden yang sangat tidak pernah, tidak pernah dan kadang-kadang stress $100 \%$ memiliki produktivitas yang tinggi.

Berdasarkan analisis menggunakan rumus Rank Spearman diperoleh nilai $\rho=0,03$ pada taraf kepercayaan $5 \%$ karena nilai $\rho=0,03$ lebih kecil dari $0,05(0,03 \leq 0,05)$ sehingga Ha diterima yang menyatakan ada hubungan antara stres kerja dengan tingkat produktivitas kerja pada bagian produksi PT.Cipta Rasa Utama Kabupaten Cirebon Tahun 2014.

\section{PEMBAHASAN}

\section{Stres Kerja}

Dalam penelitian ini ditemukan hasil stres kerja bahwa dari 45 responden, terdapat 8 orang $(17,8 \%)$ yang sangat sering mengalami stres kerja, pada kategori stres sering terdapat 27 orang $(60 \%)$, pada kategori stres kadang-kadang terdapat 1 orang $(2,2 \%)$, pada kategori stres tidak pernah terdapat 1 orang $(2,2 \%)$ dan pada kategori sangat tidak pernah terdapat 8 orang $(17,8 \%)$ yang mengalami stres kerja.

Stres kerja timbul karena tuntutan lingkungan dan tanggapan setiap individu memiliki cara yang berbeda dalam menghadapinya.Masalah stres kerja didalam organisasi perusahaan menjadi gejala yang penting untuk diamati sejak mulai timbulnya tuntutan untuk efisien didalam pekerjaan. Akibat adanya stres kerja tersebut yaitu orang menjadi sakit kepala, banyak keluar keringat dingin, gelisah, sukar konsentrasi, dan menarik diri dari pergaulan sosial. ${ }^{8}$ 


\section{Produktivitas Kerja}

Hasil dari analisa pada produktivitas kerja karyawan bagian produksi di PT.Cipta Rasa Utama Kabupaten Cirebon tahun 2014, menunjukan bahwadari 45 responden, terdapat 19responden $(47,2 \%)$ yang hasil produktivitasnya tinggi, dan 26responden $(57,8 \%)$ yang hasil produktivitasnya rendah.

Produktivitas tenaga kerja adalah hasil kerja atau kinerja seseorang dengan proses input sebagai masukan dan output sebagai keluarannya yang mempunyai indikator dari pada kinerja karyawan dalam menentukan bagaimana usaha untuk mencapai produktivitas yang tinggi dalam suatu organisasi. ${ }^{9}$

\section{Hubungan Antara Stres Kerja Dengan Produktivitas Kerja}

Berdasarkan analisis menggunakan rumus Rank Spearman hasil nilai $\rho=0,03 \leq 0,05$ bahwa ada hubungan antara stres kerja dengan tingkat produktivitas kerja pada bagian produksi PT.Cipta Rasa Utama Kabupaten Cirebon Tahun 2014 (P value <0,05).

Dalam hal ini dapat disimpulkan pula bahwa terjadi kesamaan hasil dari penelitian yang dilakukan Ita Agusnugrahaeni tentang hubungan antara stres kerja dengan produktivitas kerja pada pekerja bagian produksi PT.Indomaju Textindo Kudus tahun 2010, ditemukan adanya hubungan antara stres kerja dengan produktivitas kerja yang dikarenakan hasil dari produktivitas kerja bergantung kepada keadaan stres kerja yang dialami oleh pekerja bagian produksi di PT.Indomaju Textindo. Pada penelitian tersebut jumlah dari pegawai yang mengalami stres pada kategori sering lebih dominan menghasilkan produktivitas yang rendah. Pegawai yang mengalami stres kerja dengan kategori sering, lebih dominan dalam keadaan sering sakit kepala, mual, tidak bisa berkonsentrasi, dan mudah marah atau tidak bisa mengontrol emosi. ${ }^{5}$

Selain itu menurut pendapat A.M. Sugeng Budiono, dkk menyatakan bahwa terdapat keterkaitan yang erat antara kelelahan kerja dengan produktivitas kerja, atau lebih tepatnya kelelahan yang dialami tenaga kerja dengan kinerja perusahaan. Jika tingkat produktivitas seorang tenaga kerja terganggu dikarenakan adanya faktor kelelahan fisik maupun psikis, maka ini akan berdampak juga pada perusahaan yang berupa penurunan produktivitas perusahaan. ${ }^{9}$

Berdasarkan penelitian pada sampel yang berjumlah 45 orang, ditemukan stres kerja pada pekerja bagian produksi (Packing) di PT.Cipta Rasa Utama yang didominasi karena sakit kepala, tidak mudah berkonsentrasi, tidak bisa mengontrol emosi, dan mengalami gangguan pencernaan, hal ini yang menyebabkan penurunan hasil produktivitas pada karyawan bagian produksi (Packing) di PT.Cipta Rasa Utama kabupaten Cirebon tahun 2014. Untuk menanggulangi terjadinya stres kerja PT. Cipta Rasa Utama Kabupaten Cirebon tahun 2014 harus melakukan tindakan yang dapat mengurangi atau bahkan meniadakan faktor yang dapat menimbulkan terjadinya sttres kerja pada karyawan bagian produksi (packing).

\section{SIMPULAN}

1. Hampir dari sebagian responden (60\%) mengalami stres kerja dalam kategori sering di PT. Cipta Rasa Utama Kabuptaen Cirebon tahun 2014.

2. Hampir sebagian reponden $(57,8 \%)$ memiliki produktivitas yang rendah di PT. Cipta Rasa Utama Kabuptaen Cirebon tahun 2014.

3. Ada hubungan antara stres kerja dengan produktivitas kerja pada pekerja bagian produksi di PT. Cipta Rasa Utama Kabupaten Cirebon tahun 2014.

\section{SARAN}

1. Untuk PT.Cipta Rasa Utama

Hendaknya melakukan perubahan jam kerja dan perubahan jam istirahat untuk bisa menghilangkan keadaan yang dapat menghilangkan stres pada pekerja agar para pekerja tidak lagi sering mengalami pusing, gangguan pencernaan, tidak bisa mengontrol emosi dan tidak dapat berkonsentrasi selama bekerja sehingga para pegawai dapat bekerja lebih semangat dan 
bekerja dengan nyaman untuk meminimalisir atau menekan jumlah pegawai yang mengalami stres kerja.

2. Karyawan PT.Cipta Rasa Utama Kabupaten Cirebon.

Hendaknya setiap pekerja mempunyai manajemen diri secara mandiri yaitu dengan cara menghindari faktor-faktor yang dapat menyebabkan stres terutama stres akibat kerja. Misalnya mempertahankan kesehatan tubuh sebaik mungkin yaitu dengan berolahraga atau berekreasi, segera mencari solusi atas permasalahan yang dihadapi dalam pekerjaan, dan menggunakan metode analisa yang cukup ilmiah dan rasional dalam melihat atau menganalisa masalah stres kerja.

\section{DAFTAR PUSTAKA}

1. Linda de Clireq \& Bart Smet. Psikologi kesehatan suatu pendahuluan. Semarang :UNIKA Sugijapranata; 2006

2. Nuzep almigo. Hubungan antara kepuasankerja dengan produktivitas Kerjakaryawan.[Di akses tanggal 5 juni 2014]. Diunduh dari http://www.streskerja.pdf.2004;50

3. Soeharsono sagir dkk. Produktivitas dan mutu kehidupan. Jakarta: PT.RinekaCipta;2008.

4. Siswanto sastro hadiwiryo. Manajemen tenaga kerja indonesia.Jakarta:PT.Bumi Aksara;2004.

5. Ita Agusnugrahaeni. Hubungan antara stres kerja dengan produktivitas kerja pegawai di bagian produksi PT. Indo maju textindo Kudus. Skripsi semarang:Fakultas kesehatan masyarakat UNNES;2010

6. Soekidjo Notoatmodjo.Metodologi Penelitian Kesehatan. Jakarta: CV.Rineka cipta;2012.

7. Sugiyono.Statistik untuk penelitian.bandung: CV.Alfabetha; 2007

8. Suhartowijono.Psikologi industri dan organisasi.Jakarta:Kencana/prenada media group; 2010.

9. A.M Sugeng budiyono dkk. Bunga rampai hiperkes dan KK. Semarang:UNDIP; 2012 